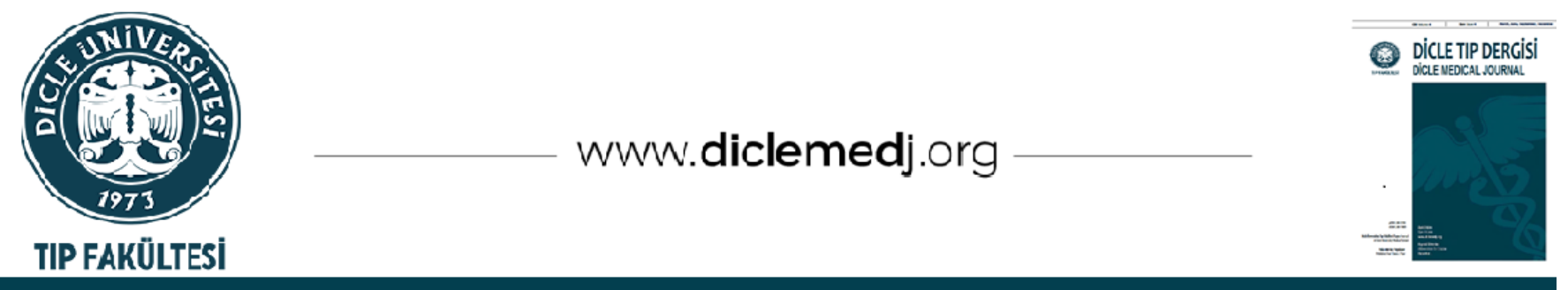

Original Article / Özgün Araştırma

\title{
Impact of COVID-19 Pandemic on Orthopedics and Traumatology Service
}

\author{
Mesut Uluöz iDsman Çiloğlu 2 \\ 1 Health Sciences University Adana City Training and Research Hospital, Orthopedics and Traumatology Clinic, \\ Adana, Turkey \\ 2 Health Sciences University Adana City Training and Research Hospital, Orthopedics and Traumatology Clinic, \\ Adana, Turkey
}

Received: 06.12.2021; Revised: 09.05.2021; Accepted: 26.05.2021

\begin{abstract}
Objectives: Each country has followed different paths in the fight against the COVID 19 pandemic that started in 2019. The pandemic and the measures taken have affected the whole country. The aim of this study was to investigate how the pandemic affected the practice in the orthopedic clinic.

Methods: Patients who presented at the Orthopedic Outpatients Clinic and Emergency Department with orthopedic complaints between March 15, 2020 and April 15, 2020, were screened. The diagnoses and treatments applied to these patients were recorded. These data were compared with equivalent periods in 2019 and 2018.

Result: There was a significant increase in home accidents, sharp object injuries and diabetic foot wounds compared to the last two years, and a decrease in workplace accidents, traffic accidents and sports injuries $(\mathrm{p}=0.040, \mathrm{p}=0.000$, $\mathrm{p}=0.037$, respectively). The frequency of hip and wrist fractures increased, and the frequency of ankle fractures decreased ( $\mathrm{p}=0.044, \mathrm{p}=0.002, \mathrm{p}=0.001$, respectively).

Conclusion: It was seen that dealing with the pandemic should not only include interventions against the causative agent. Psychological support for individuals, attention focussed on home accidents, and the provision of home exercises, especially for senior citizens, should be recommended.
\end{abstract}

Keywords: COVID 19, pandemic, hip fracture, home accidents

DOI: 10.5798/dicletip.944405

Correspondence / Yazışma Adresi: Mesut Uluöz, Orthopedics and Traumatology Adana Şehir Eğitim ve Araştirma Hastanesi Adana, Turkey e-mail: mesutuluoz@hotmail.com 


\section{COVID-19 Pandemisinin Ortopedi ve Travmatolojiye Etkisi}

\section{Öz}

Giriş: 2019 yılında başlayan COViD 19 pandemisiyle mücadelede her ülke farklı yollar izlemiştir. Pandemi ve alınan önlemler tüm ülkeyi etkilenmiştir. Biz bu çalışmamızda epideminin ortopedi kliniğinimiz pratiğini nasıl etkilediğini araştırmayı amaçladık.

Yöntemler: 2020 yılının 15 mart- 15 nisan arasında ortopedi polikliniğine ve ortopedik şikayetle acile başvuran hastalar tarandı. Tanılar ve bu hastalara uygulanan tedaviler kaydedilildi. Bu veriler 2019 ve 2018 yılının aynı dönemi ile karşılaştırıldı.

Sonuç: Ev kazaları, keskin cisim yaralanmaları ve diabetik ayak yaralarında son iki yıla göre anlamlı bir artış varken; iş kazaları, trafik kazaları, spor yaralanmalarında ciddi azalma vardır. Kalça ve el bilek kırıklarının sıklığı artarken, ayak bileği kırık sıklığı azalmıştır.

Tartışma: Salgının başlarında uygulanan kısmi sokağa çıkma yasağı ve salgın korkusu, insanları evde tutmuştur. Hareketin azalması osteosarkopeniye sebep olarak kalça ve el bilek kırklarında belirgin artışa sebep olmuştur. İnsanların hastaneden korkması ise diabetik ayak yaralarında artışa, PEV ve kalça çıkığı gibi erken tedavi gereken hastalıkların tedavisinde aksamaya sebep olmuştur. Ayrıca malign ve benign tümör cerrahisinde de belirgin azalma hizmetin aksadığını göstermektedir. Epidemi ile mücadelede izole merkezler kurulması kronik hastaların ve erken tedavi gerektiren hastaların olumsuz etkilenmesinin önüne geçecektir.

Çıkarımlar: Sonuç olarak salgınla mücadele sadece patojenin yol açtı̆̆ı hastalığa karşı yapılmamalıdır. Halkın psikolojisi desteklenmeli, ev kazalarına dikkat çeklimelidir. Ev içi egzersizler ve takip için ise aile hekimlerine ciddi görev düşmektedir.

Anahtar kelimeler: COVID 19, pandemi, kalça kırığı, ev kazaları.

\section{INTRODUCTION}

COVID 19 started as an epidemic in Wuhan, China in 2019, and was declared a pandemic by the World Health Organization (WHO) on March 11,2020 . The virus was first named the novel coronavirus-2019 (2019-nCoV), then later, "Serious Acute Respiratory SyndromeCoronavirus-2" (SARS-CoV-2) and the disease caused by this virus was named CoronaVirus Disease 2019 (COVID-19) by the WHO ${ }^{1,2}$.

COVID-19 is the first reported pandemic since the H1N1 pandemic in 2009, and the early mortality rate was reported as $0.4 \%-4.3 \%$. This rate is lower than the mortality rate in Severe Acute Respiratory Syndrome (SARS) and Middle East Respiratory Syndrome (MERS) ${ }^{3,4}$. However, since the pandemic period has not yet ended at the time of writing, exact values for COVID-19 have not been revealed.
Many countries throughout the world have taken different approaches to survive this pandemic with minimal damage. With the catastrophic worldwide spread of the disease, measures were taken by the Ministry of Health of the Republic of Turkey at the first appearance of cases and a scientific committee was created. In line with the views of the scientific committee, measures such as school closures, working from home, and curfews were taken.

Many hospitals in Turkey were converted into pandemic hospitals. The number of clinical beds in these hospitals was reduced and allocated for pandemic patients, and doctors, nurses and auxiliary personnel were assigned to these areas. Operating room table numbers were considerably reduced, as only urgent surgical interventions were permitted. Outpatient clinics were reduced to $30 \%$, and patients were not accepted without an appointment. 
Despite the presence of disease, both the curfew and fear of transmission caused patients to stay at home for as long as they could withstand the symptoms. When these diseases become irreversible, presenting at a hospital may cause difficulties and failures in treatment ${ }^{5}$.

The aim of this study was to investigate how the coronavirus pandemic has affected the orthopedic emergency and clinical services and to develop preparation and planning for possible future epidemics.

Some studies have compared the last year and evaluated only the Emergency Deparment ${ }^{6,7}$, whereas in the current study, the evaluation was made of patients admitted to the Emergency Clinic and the Orthopaedics Outpatient Clinic and the surgical procedures performed during this period were screened.

The hypothesis of the study was that the COVID19 pandemic would have resulted in reductions in orthopedic service provision in terms of surgical volume, hospitalizations, clinic appointments, and accident and emergency attendances, with more pronounced reductions in elective than emergency clinical services. This is one of the first studies to have analyzed how the pandemic has affected an Orthopedic and Traumatology Department.

\section{METHODS}

This epidemiological retrospective study was carried out in compliance with the principles outlined in the Declaration of Helsinki. Ethics approval was granted by the Institutional Review Board of the University hospital (20/05/2020 No:881). The study was conducted in a tertiary level hospital, located in the sixth-largest city in Turkey, which has a population of 2.5 million.

Medical records, including in-patient hospitalizations, outpatient clinic attendances, surgical operations performed, and accident and emergency department attendances, were retrieved from the territory-wide clinical data repository. Diagnoses and procedures were encoded according to the International Classification of Diseases, 9th Edition, Clinical Modification (ICD-9-CM).

The time periods studied and compared were the 2-month period of March 15 to May 15, 2020 (Period 1), March 15 to May 15, 2019 (Period 2), and March 15 to May 15, 2018 (Period 3).

The inclusion criteria for patients were: 1) orthopedics consultation requested for patients presenting at the hospital Emergency Department. 2) presentation at the Orthopedics Outpatient Clinic. If the same patient presented at both the Emergency Department and the Outpatient Clinic, this was considered as two separate patients.

The variables collected were patient age and gender, admitting diagnosis, the procedure applied, and length of stay.

\section{Statistical Analysis}

Data obtained in the study were analyzed statistically using SPSS vn 23.0 software. Categorical measurements were summarized as number (n) and percentage (\%), and continuous measurements as mean \pm standard deviation (SD), minimum and maximum values. The Chi-square test and Fisher Exact tests were used in comparisons of categorical data. A value of $\mathrm{p}<0.05$ was accepted as statistically significant.

\section{RESULTS}

Evaluation was made of 4226 patients who presented at the ED and required orthopedics and traumatology consultation, comprising 1674 in Period 1, 1236 in Period 2, and 1316 in Period 3. The number of patients admitted to the Outpatients Clinic was 4299 in Period 1, 14956 in Period 2, and 11611 in Period 3. Of the patients who presented at ED with orthopaedic complaints in Period 1, 892 were male, and 782 were female, with an average age of 43 years, and of these, 256 patients were hospitalized in 
the orthopedic clinic. In Period 2, of the patients who presented at ED with orthopaedic complaints, 652 were male, and 584 were female, with an average age of 39 years, and of these, 320 patients were hospitalized in the orthopedic clinic. In Period 3, of the patients who presented at ED with orthopaedic complaints, 653 were male, and 663 were female, with an average age of 38 years, and of these, 305 patients were hospitalized in the orthopedic clinic. Together with the patients hospitalized from the Outpatients Clinic, 578 patients in Period 1, 1170 patients in Period 2, and 1078 patients in Period 3 were admitted to the orthopedics and traumatology clinic.

Table I: Application Injury Complaints

\begin{tabular}{|c|c|c|c|c|}
\hline \multirow{2}{*}{$\begin{array}{l}\text { APPLICATION } \\
\text { INJURY } \\
\text { COMPLAINTS }\end{array}$} & $\begin{array}{r}\text { Period } 1 \\
2020 \\
(683)\end{array}$ & $\begin{array}{r}\text { Period } 2 \\
2019 \\
(585)\end{array}$ & $\begin{array}{r}\text { Period } 3 \\
2018 \\
(615) \\
\end{array}$ & \multirow[t]{2}{*}{$\mathbf{p}$} \\
\hline & $n(\%)$ & $n(\%)$ & $n(\%)$ & \\
\hline $\begin{array}{l}\text { DIABETIC } \\
\text { FOOT WOUND }\end{array}$ & $38(5.6)$ & $19(3.2)$ & $16(3.1)$ & 0.039 \\
\hline $\begin{array}{l}\text { SPORTS } \\
\text { INJURY }\end{array}$ & $4(0.6)$ & $12(2.1)$ & $15(2.0)$ & 0.037 \\
\hline $\begin{array}{l}\text { FIREARM } \\
\text { INJURY }\end{array}$ & $38(5.6)$ & $25(4.3)$ & $22(4.1)$ & 0.380 \\
\hline $\begin{array}{l}\text { BLADE / } \\
\text { SHARP BODY } \\
\text { INJURY }\end{array}$ & $241(35.3)$ & $131(22.4)$ & $135(21.3)$ & 0.000 \\
\hline $\begin{array}{l}\text { INJURY WITH } \\
\text { THE DARP }\end{array}$ & 55 (8.1) & $33(5.6)$ & $37(6.0)$ & 0.171 \\
\hline $\begin{array}{l}\text { FALLING } \\
\text { FROM HIGH }\end{array}$ & $15(2.2)$ & $13(2.2)$ & $14(2.3)$ & 0.995 \\
\hline $\begin{array}{ll}\text { FALLING } & \text { AT } \\
\text { LADDER } & \text { AT } \\
\text { HOME } & \\
\end{array}$ & $28(4.1)$ & $10(1.7)$ & $5(0.8)$ & 0.000 \\
\hline $\begin{array}{l}\text { FALLING } \\
\text { FROM TREE }\end{array}$ & $-^{(0.0)}$ & $4(0.7)$ & $7(1,1)$ & 0,025 \\
\hline $\begin{array}{l}\text { TRAFFIC } \\
\text { ACCIDENT }\end{array}$ & $179(26.2)$ & $288(49.2)$ & 297(48.3) & 0,000 \\
\hline $\begin{array}{l}\text { WORK } \\
\text { ACCIDENT }\end{array}$ & $9(1.3)$ & 17 (2.9) & $21(3.4)$ & 0,040 \\
\hline $\begin{array}{l}\text { GENERAL } \\
\text { HAND } \\
\text { INJURY / } \\
\text { HAND } \\
\text { SURGERY } \\
\text { REQUIRED } \\
\end{array}$ & $74 / 116(10.8)$ & $27 / 25(4.6)$ & $38 / 29(6.2)$ & 0,000 \\
\hline SNAKE BITE & $2(0.122)$ & $6(1.0)$ & $8(1.3)$ & 0,122 \\
\hline
\end{tabular}

Table II: Type of Fracture

\begin{tabular}{|lrrrrr|}
\hline \multirow{2}{*}{ FYPE } & OF & $\begin{array}{r}\text { Period 1 } \\
\mathbf{2 0 2 0}\end{array}$ & $\begin{array}{r}\text { Period 2 } \\
\mathbf{2 0 1 9}\end{array}$ & $\begin{array}{r}\text { Period 3 } \\
\mathbf{2 0 1 8}\end{array}$ & $\mathbf{p}$ \\
\cline { 2 - 4 } & $\mathbf{n ( \% )}$ & $\mathbf{n}(\%)$ & $\mathbf{n}(\%)$ & \\
\hline CLAVICLE & $30(4.0)$ & $37(5.0)$ & $41(5.6)$ & 0.354 \\
\hline SCAPULA & $9(1.2)$ & $11(1.5)$ & $0(0.0)$ & $\mathbf{0 . 0 0 6}$ \\
\hline HUMERUS & $86(11.5)$ & $86(11.6)$ & $91(12.5)$ & 0.818 \\
\hline FOREARM & $205(27.5)$ & $186(25.1)$ & $190(26.1)$ & 0.568 \\
\hline ACETABULUM & $3(0.4)$ & $2(0.3)$ & $4(0.5)$ & 0.701 \\
\hline HIP & $84(11.3)$ & $66(8.9)$ & $55(7.6)$ & $\mathbf{0 . 0 4 4}$ \\
\hline FEMUR & $66(8.9)$ & $64(8.6)$ & $58(8.0)$ & 0.816 \\
\hline PATELLA & $8(1.1)$ & $10(1.3)$ & $9(1.2)$ & 0.888 \\
\hline TIBIA & $58(7.8)$ & $80(10.8)$ & $65(8.9)$ & 0.127 \\
\hline FOOT / ANKLE & $79(10.6)$ & $125(16.9)$ & $115(15.8)$ & $\mathbf{0 . 0 0 1}$ \\
\hline HAND / HAND & $114(15.3)$ & $69(9.3)$ & $86(11.8)$ & $\mathbf{0 . 0 0 2}$ \\
\hline WRIST & $3(0.4)$ & $5(0.7)$ & $1(0.1)$ & 0.270 \\
\hline COCCYX & & & & \\
\hline
\end{tabular}

Emergency patients were classified as traumatic injuries, diabetic foot ulcers and pain. The complaints of the patients on a presentation at ED are shown in Table 1. Of these ED presentations, 805 patients in Period 1, 704 in Period 2, and 692 patients in Period 3 were diagnosed with fractures. The dislocation was diagnosed in 35 patients in Period 1, 26 patients in Period 2, and 25 patients in Period 3. The distribution of the diagnoses is shown in Table 2 and Table 3. Interventions performed both in the Outpatients Clinic and under operating room conditions were evaluated, and classified according to the procedures made Table 4.

Table III: Dislocations / Bucklıng

\begin{tabular}{|lrrrr|}
\hline $\begin{array}{l}\text { DÍSLOCATIONS } \\
\text { BUCKLING }\end{array}$ & $\begin{array}{r}\text { Period 1 } \\
\mathbf{2 0 2 0}\end{array}$ & $\begin{array}{r}\text { Period 2 } \\
\mathbf{2 0 1 9}\end{array}$ & $\begin{array}{r}\text { Period 3 } \\
\mathbf{2 0 1 8}\end{array}$ & $\mathbf{p}$ \\
\hline LOWER & $\mathbf{n ( \% )}$ & $\mathbf{n}(\%)$ & $\mathbf{n ( \% )}$ & \\
\hline EXTREMITY & $3(8.8)$ & $5(19.2)$ & $6(19.4)$ & 0.408 \\
\hline $\begin{array}{l}\text { UPPER } \\
\text { EXTREMITY }\end{array}$ & $31(91.2)$ & $21(80.8)$ & $25(80.6)$ & 0.388 \\
\hline
\end{tabular}


Table IV: Treatments Applied

\begin{tabular}{|c|c|c|c|c|}
\hline TREATMENTS APPLIEED & $\begin{array}{r}\text { Period } 1 \\
2020 \\
\end{array}$ & $\begin{array}{r}\text { Period } 2 \\
2019 \\
\end{array}$ & $\begin{array}{r}\text { Period } 3 \\
2018 \\
\end{array}$ & p \\
\hline & n(\%) & n(\%) & n(\%) & \\
\hline SMALL BONE / JOINT TREATMENTS & $49(8.1)$ & $119(11.4)$ & $132(13.0)$ & 0.012 \\
\hline MIDDLE BONE / JOINT TREATMENTS & $45(7.5)$ & $42(4.0)$ & $48(4.7)$ & 0.007 \\
\hline OPEN REDUCTION INTERNAL FIXATION & $29(4.8)$ & $22(2.1)$ & $26(2.6)$ & 0.005 \\
\hline JOINT PARTIAL PROSTHESES & $52(8.6)$ & $41(3.9)$ & $34(3.3)$ & 0.000 \\
\hline PROKSIMAL FEMORAL NAİL & $32(5.3)$ & $25(2.4)$ & $23(2.3)$ & 0.001 \\
\hline BİG BONE FRACTURE CLOSED REDUCTION & $285(47.3)$ & $267(25.6)$ & $245(24.1)$ & 0.000 \\
\hline LARGE BONE / JOINT AMPUTATION & $11(1.8)$ & $23(2.2)$ & $25(2.5)$ & 0.705 \\
\hline PEV PLASTER / SURGERY & $34 / 0(5.6)$ & $109 / 13(10.5)$ & $98 / 15(9.6)$ & 0.003 \\
\hline HIP DISLOCATION SURGERY & $0(0.0)$ & $12(1.2)$ & $10(1,0)$ & 0.036 \\
\hline $\begin{array}{|lll|}\text { CUTTING SUTURATION } & / & \text { WOUND } \\
\text { TREATMENT } & & \\
\end{array}$ & $27 / 35(4.5)$ & $12 / 26(1.2)$ & $19 / 29(1.9)$ & 0.000 \\
\hline SPINE SURGERY & $8(1.3)$ & $20(1.9)$ & $18(1.8)$ & 0.669 \\
\hline SPORTS SURGERY AND ARTROSCOPY & $15(2.5)$ & $121(11.6)$ & $112(11.0)$ & 0.000 \\
\hline ARTHROPLASTY & $3(0.5)$ & $167(16.0)$ & $155(15.2)$ & 0.000 \\
\hline ARTHROPLASTY REVISION & $7(1.2)$ & $25(2.4)$ & $28(2.8)$ & 0.105 \\
\hline TUMOR PROSTHESIS & $0(0.0)$ & $6(0.6)$ & $7(0.7)$ & 0.138 \\
\hline TUMOR SURGERY MALIGN / BENİGN & $6 / 4(1.0)$ & $21 / 53(2.0)$ & $23 / 48(2.3)$ & 0.177 \\
\hline DEFORMITY SURGERY & $0(0.0)$ & $5(0.5)$ & $7(0.7)$ & 0.134 \\
\hline HALLUX VALGUS & $0(0.0)$ & $4(0.4)$ & $5(0.5)$ & 0.244 \\
\hline CORE DECOMPRESSION & $0(0.0)$ & $2(0.2)$ & $3(0.3)$ & 0.415 \\
\hline
\end{tabular}

\section{DISCUSSION}

The results of this comparative study showed a significant increase in the number of patients who presented at ED in Period 2 compared to Period 1, which could be attributed to the difficulties experienced by patients in reaching outpatient clinics during the pandemic. Although there were more presentations at ED, significantly fewer patients were hospitalized, which unnecessarily increases the workload of the emergency room, which is the front line in combating the pandemic. At this stage, primary healthcare centers have a greater duty, as at such times, this intensity can be eliminated by directing non-emergency patients to primary health care facilities or outpatient clinics with triage established outside the ED.
According to a study conducted in Turkey, domestic violence has been shown to increase by $27.8 \%$ during the pandemic ${ }^{8}$. With a prolonged quarantine-isolation process, anxiety and psychosis develop, and alcohol and drug use may increase ${ }^{8,9}$. This was reflected in the current study, with a significant increase in gunshot injuries, injuries with a knife or sharp object, and assault. Social problems unrelated to orthopedics indirectly increase the clinical burden of orthopedics. It can be recommended that during periods of quarantine or curfew, content aimed at preventing violence should be added to television public information slots.

It would be wrong to attribute all the injuries with a knife or sharp object only to violence, as laceration and penetrating, puncture-type accidents are common among home accidents. 
It was thought that home accidents could account for the increase in injuries with a knife or sharp object in this study, as there was also a significant increase in injuries resulting from a fall from a ladder, which is seen as another type of home accident. Public information for the prevention of home accidents should be increased during these periods when more time is spent at home. Although there was determined to be a significant increase in hand injuries during the pandemic, there was no significant difference in the number of patients requiring intervention by the hand surgeon.

For a small part of the two-month period in 2020 covered by the study, a curfew was imposed. This resulted in a significant reduction in sports injuries, snake bites and falls from trees. The significant reduction in occupational accidents in the current study was seen to be compatible with the literature information ${ }^{6}$. Despite the decrease in workplace accidents, a minimal increase in falls from height was observed in the current study. This was thought to be due to the habits of some local people in this region of spending time on the roof and flying a kite in this season. This view is supported by the fact that most of the patients diagnosed with falls were children.

Diabetic foot ulcers cause increased morbidity, impaired quality of life, high treatment costs, and a high rate of lower limb amputations ${ }^{10}$. There are publications reporting that the average age of foot wound development in diabetics is 65 years $^{10}$. For the abovementioned reasons of fear of disease transmission and transport difficulties during the pandemic, diabetic patients over 65 years of age found it difficult to reach the hospital and psychological reasons due to the pandemic disrupted diabetes regulation, resulting in foot wounds. A significant difference in foot wounds between Periods 1 and 2 supports this view.

Pes eqinovarus (PEV) and developmental hip dysplasia, for which early treatment increases the chances of success, were also affected. During the two-month period of 2020, there was a significant reduction in plaster cast applications for PEV treatment, while no PEV or hip dysplasia surgery was performed.

The surgical treatment of tumor patients can be seriously reduced and it is desirable to keep these immune-compromised patients away from the hospital environment. During pandemic periods, the establishment of small, isolated hospitals for patients with weak immune systems, such as malignant tumor patients, should be included in the emergency plan. In a study conducted in Spain by Nunez et al, there was reported to be no change in the number of hip fractures despite a decrease in all types of injuries ${ }^{6}$. In the current study, there was a significant increase in the number of patients operated on for the diagnosis of hip fracture. There are publications reporting that immobilization causes both sarcopenia and osteopenia, which could explain this result ${ }^{11}$. In Turkey, citizens over 65 years of age were completely confined to home for a long period, and this immobility could have caused osteosarcopenia, which led to the significant increase in the number of patients with hip fractures in the study period during the pandemic. In a study conducted by Turgut at all, they reported that there should be an increase in advanced age hip fractures, but they did not encounter a significant increase as a result of the study ${ }^{12}$. After reading this study, we evaluated the number of hip fractures in the second largest hospital in our city. When the total number of hip fractures of the two hospitals was compared, there was a significant increase in period 1 compared to the other periods. (p: 0.041)

Hip fractures in the elderly population usually occur in the home environment. With the increase in the time spent at home, both increased home accidents and supported sedentary life. There is no scientific basis for 
developing osteosarcopenia in such a short time. However, it is seen that hip and wrist fractures increase with the increase of home accidents. In the fight against COVID 19, advanced age hip fractures, which are in the risk group, should not be ignored. Surgery of these patients should be completed immediately and should be removed from the risk environment.

The limitation of our study is that it is limited to the data of our hospital. Studies on a larger scale will yield more meaningful results.

\section{CONCLUSION}

In conclusion, when dealing with a pandemic there should not only be interventions against the causative agent or the primary disease. Psychological support for individuals, attention focussed on home accidents, and the provision of home exercises, especially for senior citizens, should be recommended. As a result, while there might be no osteopenia in such a short period of time, we must keep in mind that we should be stronger in the fight against any potential pandemic.

Ethics Committe Approval: This epidemiological retrospective study was carried out in compliance with the principles outlined in the Declaration of Helsinki. Ethics approval was granted by the Institutional Review Board of the University hospital (20/05/2020 No:881). The study was conducted in a tertiary level hospital, located in the sixth-largest city in Turkey, which has a population of 2.5 million.

Decleration of Conflicting Interest: The authors declare no conflict of interest.

Financial Disclosure: The authors declare no financial support fort his study.

\section{REFERENCES}

1. Cucinotta D, Vanelli M. WHO Declares COVID-19 a Pandemic. Acta Bio-medica : Atenei Parmensis. 2020; 91: 157-60.
2. Neher, R. A., Dyrdak R., et al. Potential impact of seasonal forcing on a SARS-CoV-2 pandemic. Swiss medical weekly, 2020: 150 (1112).

3. Wang D, Hu B, Hu C, et al. Clinical characteristics of 138 hospitalized patients with 2019 novel coronavirus-infected pneumonia in Wuhan, China. Jama 2020; 323: 1061-9.

4. Xu X-W, Wu X-X, Jiang X-G, et al. Clinical findings in a group of patients infected with the 2019 novel coronavirus (SARS-Cov-2) outside of Wuhan, China: retrospective case series. bmj 2020; 368.

5. England N. Clinical guide for the management of trauma and orthopaedic patients during the coronavirus pandemic. 2020; 51: 2142-7

6. Nuñez JH, Sallent A, Lakhani K, et al. Impact of the COVID-19 Pandemic on an Emergency Traumatology Service: Experience at a Tertiary Trauma Centre in Spain. Injury 2020; 51: 1414-8

7. Wong JSH, Cheung KMC. Impact of COVID-19 on Orthopaedic and Trauma Service: An Epidemiological Study. JBJS . 2020; 102: e80(1-9)

8. Ergönen AT, Biçen E, Ersoy G. COVID-19 Salgınında Ev İçi Şiddet. The Bulletin of Legal Medicine 2020; 25(Sp): 48-57.

9. Brooks SK, Webster RK, Smith LE, et al. The psychological impact of quarantine and how to reduce it: rapid review of the evidence. The Lancet 2020; 395: 912-20

10. Nural N, Hintistan S. Diyabetik Hastaların Ayak Bakımıyla İlgili Bilgi Ve Tutumlarının İncelenmesi. Anadolu Hemşirelik ve Sağlık Bilimleri Dergisi 2015; 18: 116-24.

11. Amarya S, Singh K, Sabharwal M. Ageing Process and Physiological Changes. Gerontology. IntechOpen; 2018. doi:10.5772/intechopen.76249

12. Turgut A, Arlı H, Altundağ Ü, et al. Effect of COVID19 pandemic on the fracture demographics: Data from a tertiary care hospital in Turkey. Acta Orthop Traumatol Turc. 2020; 54: 355-63. 